\title{
Modeling the Influence of Forest Structure on Microsite Habitat Use by Snowshoe Hares
}

\author{
Angela K. Fuller ${ }^{1,2}$ and Daniel J. Harrison ${ }^{1}$ \\ ${ }^{1}$ Department of Wildlife Ecology, University of Maine, 210 Nutting Hall, Orono, ME 04469, USA \\ ${ }^{2}$ U.S. Geological Survey, New York Cooperative Fish and Wildife Research Unit, Department of Natural Resources, \\ 211 Fernow Hall, Ithaca, NY 14853, USA \\ Correspondence should be addressed to Angela K. Fuller; angela.fuller@cornell.edu
}

Received 20 May 2013; Revised 19 August 2013; Accepted 26 August 2013

Academic Editor: Ursula Nopp-Mayr

Copyright (C) 2013 A. K. Fuller and D. J. Harrison. This is an open access article distributed under the Creative Commons Attribution License, which permits unrestricted use, distribution, and reproduction in any medium, provided the original work is properly cited.

\begin{abstract}
Snowshoe hare (Lepus americanus) is an important prey species for many Carnivora and has strong influences on community structure and function in northern forests. An understanding of within-stand (microsite) forest structural characteristics that promote high use by hares is important to provide forest management guidelines. We measured forest structural characteristics at the microsite-scale in north-central Maine and used an information-theoretic modeling approach to infer which characteristics were most strongly associated with use by hares during winter. We measured overwinter hare pellet density to model relationships among microsite-scale vegetation structure and hare use. Overwinter pellet density was positively associated with live stem cover $(3 \times$ coniferous saplings + deciduous saplings) and negatively associated with overstory canopy closure; the two variables explained $71 \%$ of the variation in microsite use by hares. The highest pellet densities were in grids with canopy closure $<72 \%$ and stem cover units $>22,000$ stems/ha. Silvicultural practices that create dense areas of conifer and deciduous saplings should receive high within-stand use by hares in winter. These conditions can be achieved by promoting the release of advanced regeneration and reducing overstory cover to encourage establishment of shade-intolerant species; clearcutting is one such silvicultural prescription to achieve these conditions.
\end{abstract}

\section{Introduction}

Snowshoe hare (Lepus americanus) have been reported to strongly influence community structure and function in northern boreal forests [1] and is an important prey species for many Carnivora including coyotes (Canis latrans) [24], fisher (Martes pennanti) [5, 6], American marten (Martes americana) [7-9], bobcat (Lynx rufus) [3], red fox [3, 10], and Canada lynx (Lynx canadensis) [11, 12]. Of special importance is the Canada lynx, which is designated as federally threatened in the lower 48 US [13] and is listed as provincially threatened (New Brunswick) or endangered (Nova Scotia) in some provinces of Eastern Canada. The lynx is a specialist on snowshoe hares [11, 12], and habitat use by lynx is closely associated with density of hares [4, 14-18].

Survival of snowshoe hares may be lower in forest stands with little understory cover $[2,19,20]$, and overall survival depends on stand-specific hare density, presence of predators, and the hunting success of predators [21]. The refugium of hares from predation that is provided by dense stands is evident during the lows in the snowshoe hare cycle when the few surviving individuals persist in patches of dense vegetation [22]. Silvicultural practices or large-scale natural disturbance events (e.g., blowdowns and insect kills) that promote the development of stands with dense understory structure have been recommended to decrease the visibility of hares to predators [17]. However, hares exposed to terrestrial predation during a cyclic low in the population did not use more protected habitats and did not modify their foraging behavior to reduce the risk of predation [23], suggesting that behavioral plasticity of hares may be limited (i.e., they may select for dense understory structure across a range of hare and predator densities).

At the scale of the forest stand, vegetation structure is more important than species composition for snowshoe hares [24]. Important forest structural characteristics for hares 
include understory lateral foliage density [24-26] and canopy closure [27], but see Wirsing et al. [28]. Additionally, density of snowshoe hare across stands is positively associated with dense understories of saplings and/or shrub-sized woody vegetation [25-30] with abundant horizontal cover [31] that provides hares cover from predation $[2,20,32]$ and a source of browse [26, 33]. At the scale of the forest stand, there was a strong relationship between hare density and stem cover units (SCU $=3 \times$ coniferous saplings + deciduous saplings) in eastern and western Maine, USA; SCUs were an important determinant of between-stand differences in hare density [26]. The variable SCU adjusts for a difference in visual obstruction of softwood stems; therefore, high values were inferred to indicate greater thermal or predator escape cover for hares [26]. Other studies from Maine indicated that standscale density of hares was highest in regenerating clearcuts $[9,34]$ where understory stem densities were greatest, and densities of hares were an order of magnitude greater than other stand types [9]. Densities were intermediate in clearcut stands where regenerating understory was thinned [34] and were lowest in mature and recent partially harvested stands where understory stems were relatively sparse [9]. Contrary to results from Maine, woody stem density was not a significant predictor of hare pellet counts in Wyoming, but horizontal cover was significant [31]; this suggests that functional needs of hares for thermal and escape cover may be met in different ways in different regions.

Most studies investigating the relationship of vegetation structure and snowshoe hares have focused on hare density across stand types, or the relationship between hare density and structural characteristics. A notable exception was a study conducted in the Yukon Territories, Canada, which reported that $83 \%$ of hare browsing occurred within $1 \mathrm{~m}$ of cover [23]. Thus, a better understanding of how within-stand patchiness and structural variability within stands affects microsite-scale use by hares could provide recommendations for silvicultural activities that promote the fine-scale structural requirements of hares. Further, knowledge of withinstand habitat use by hares may facilitate inferences about structural features important to maintain in managed forests. Smaller microsite or within-stand scale studies that are at a scale smaller than the home range size of hares and that do not focus on hare density are not common (but see foraging studies by Hodges and Sinclair [23] and Wolfe et al. [25] and within-stand hare use studies by Ausband and Baty [35]) but could offer insights into use of specific structural elements within stands. Further, there should be no assumption that hares would use the same structural features across all spatial scales.

Thus, we identified within-stand scale structural attributes that are important in describing why individual hares use particular forest structural characteristics on 0.49 ha grids at a scale that was a magnitude smaller than the area of a hare home range (4.8-7.4 ha) in Maine [36] and well over a magnitude smaller than the size of forest stands (>12.1 ha) in which our grids were imbedded. We modeled the relationship of snowshoe hare fecal pellet density with forest structure using an information-theoretic approach and

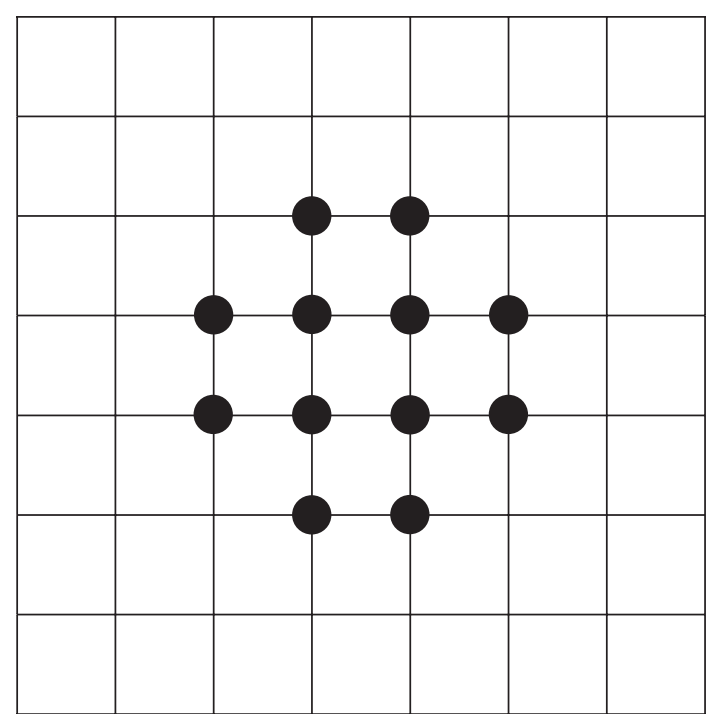

FIgUre 1: Position of $12,5 \mathrm{~m} \times 30 \mathrm{~cm}$ plots, placed $10 \mathrm{~m}$ apart within a $70 \mathrm{~m} \times 70 \mathrm{~m}$ grid used to sample snowshoe hare pellets.

evaluated relative differences in pellet density as related to forest structure across microsite plots.

\section{Materials and Methods}

2.1. Study Area. Our study area $\left(138 \mathrm{~km}^{2}\right)$ was located in 2 townships in north-central Maine (T4 R11 WELS and T5 R11 WELS). The area was managed for pulpwood and saw timber, and approximately $56 \%$ of the area was clearcut during 1974-1994. Dominant species in second-growth deciduous stands included red maple (Acer rubrum), sugar maple (A. saccharum), American beech (Fagus grandifolia), paper birch (Betula papyrifera), and yellow birch (B. alleghaniensis). Second-growth coniferous forests were composed of balsam fir (Abies balsamea), red spruce (Picea rubens), and white pine (Pinus strobus). Forests regenerating from clearcutting were primarily composed of balsam fir, red spruce, red maple, paper birch, and raspberries (Rubus sp.). This study area was described in detail by Fuller and Harrison [9].

2.2. Snowshoe Hare Pellet Count Survey Methodology. We used overwinter fecal pellet counts as an index of microsite use within stands. Fecal pellet counts [37-39] have been used as a reliable index of overwinter abundance of snowshoe hares [22, 37, 40-43]. For our approach, we were not interested in estimating abundance or density, but, rather, we simply used pellet counts as an index to hare use within microsite plots. We established 300 pellet plots and counted hare pellets during 1996 and 1998 within $12,5 \mathrm{~m} \times 30 \mathrm{~cm}$ plots, placed $10 \mathrm{~m}$ apart within $25,70 \mathrm{~m} \times 70 \mathrm{~m}$ grids ( $0.49 \mathrm{ha})$, to ensure that we sampled variation in forest structure within each stand type (Figure 1). Each grid represents the experimental unit, which was placed within a relatively homogenous stand of approximately $14 \mathrm{ha}$. The 12 plots in each of the 25 grids (Figure 2) were placed at the intersection of a $10 \mathrm{~m}$ grid cell and oriented randomly, at the center of the grid. Thus, only 


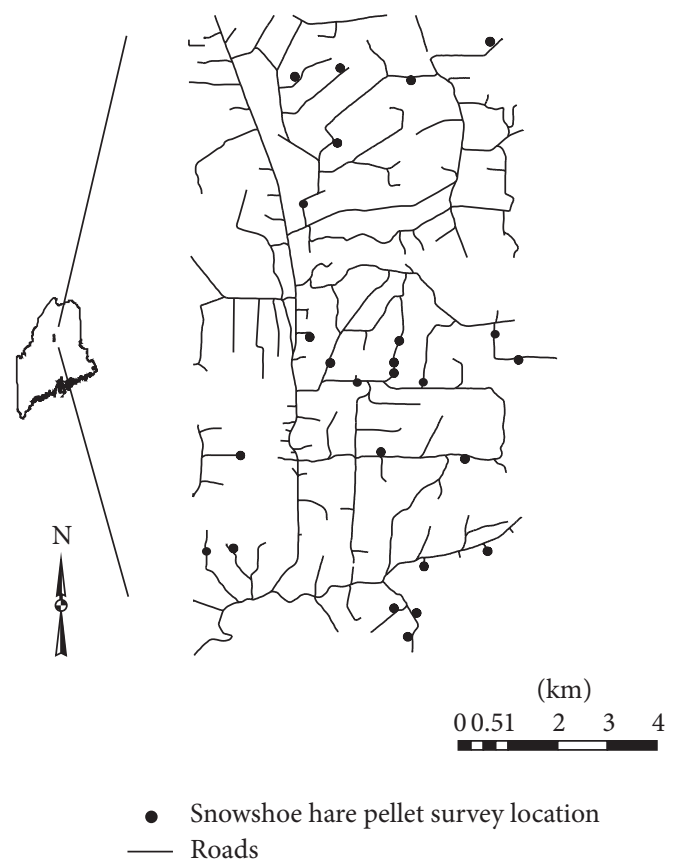

FIgURE 2: Location of study area and 25 snowshoe hare pellet survey locations within T4 R11 and T5 R11 WELS (460211.85N and 690910.62W), northcentral Maine.

one grid was sampled in each stand. Data from each of the 12 plots per grid were pooled to represent average conditions within the 25 grids. Grids were placed within overstory types that included regenerating clearcuts (11-20 years old; $n=$ 7; 5 in 1996, 2 in 1998), second-growth mixed coniferousdeciduous ( $n=7$ grids; 3 in 1996, 4 in 1998) stands, secondgrowth mixed stands that were recently (3-6 years after harvest) partially harvested ( $n=7$; sampled in 1998), secondgrowth deciduous ( $n=2 ; 1$ in 1996, 1 in 1998) stands, and second-growth coniferous ( $n=2$; 1 in 1996, 1 in 1998) stands to ensure that the habitats that we sampled included the range of conditions found within dominant silvicultural treatments and stand conditions in our study area. Our analyses were designed to evaluate microsite or within-stand scale use of forest structure by hares using the relative difference in pellet densities across the range of within-stand structural variables that hares would typically encounter and were not intended to provide predictions of hare density across stands. Plots were cleared of all pellets during October of 1995 and 1997, and pellets deposited during winter and prior to emergence of deciduous leaves were counted during May of the following year. Clearing pellets avoided the potential confounding effects of seasonal variation in pellet deposition rates, diet quality, and decomposition rates of pellets $[43,44]$ and likely increased precision [45]. We averaged values across the 12 plots within each sampling grid.

2.3. Forest Structure Sampling. We measured forest structure variables on the hare pellet plots; therefore, the vegetation measurements correspond to structural characteristics at the same location as pellets were deposited. We measured structural variables on $10 \mathrm{~m} \times 2 \mathrm{~m}$ rectangular plots during summers 1995 and 1997. We measured density of coniferous and deciduous saplings ( $<7.6 \mathrm{~cm}$ dbh, $0.5-1.5 \mathrm{~m}$ height, alive), percent overhead canopy closure using a spherical densiometer [44], and basal area of live deciduous and coniferous trees using a $2 \mathrm{~m}^{2} /$ ha wedge prism. Understory lateral foliage density was estimated by recording visual obstruction for each $0.5 \mathrm{~m}$ zone $(0-0.5,0.5-1.0,1.0-1.5$, and $1.5-2.0 \mathrm{~m})$ on a $2.0 \mathrm{~m}$ cover pole as the percent of $0.1 \mathrm{~m}$ bands $\geq 25 \%$ obstructed by vegetation [46]. We averaged each habitat variable across 12 sampled plots to produce an average value within each 0.49 ha grid. We screened for multicollinearity with a Pearson correlation matrix $(r)$, and, based on the recommendation by Burnham and Anderson [47], we retained all variables with $|r| \leq 0.95$.

2.4. Snowshoe Hare Model. We evaluated alternative linear regression models to determine which forest structural variables best described microsites with the greatest density of snowshoe hare pellets. We examined the assumption of normal errors with normal probability plots and Lilliefor's test and examined the data for constant variance with plots of the residuals [48]. We transformed data exhibiting heteroscedasticity or nonnormal errors. Our set of biological hypotheses was based on within-stand variables known to influence snowshoe hare density and or risk of predation, and we therefore did not record species of trees or saplings, but rather their overall density or basal area. We considered understory lateral foliage density, which is predicted to influence hare densities via lateral visibility to predators [25-27]. Overhead canopy closure and basal area of trees and snags were included as variables for their potential to reduce understory density, which could potentially increase the visibility of predators of hares. We included the four single variable models (SCU, canopy closure (CC), basal area (BA), understory lateral foliage density (ULFD)), a global model, and 3 models with 2 variables (SCU + CC, CC + ULFD, ULFD + BA). Stem cover units and overhead canopy closure were included in a model because dense overhead cover is likely to reduce density and diversity of understory stems and, hence, abundance of hares. We included two models that described variables related to access to hares by avian and mammalian predation. Both models included ULFD because of its potential association with access to hares and visibility by predators. Canopy closure was added to one model and basal area to the other to determine which was more important in combination with ULFD. We also evaluated a year-only model since we include plots that were sampled in two different years. Pellet density (pellets/ha/month) was used as the dependent variable in our models. Pellet data were averaged across the 12 plots within each 0.49 ha grid, representing a sample size of 25 grids.

We used an information-theoretic approach based on Kullback-Leibler (K-L) information to rank multiple a priori models selected based on previously defined relationships between snowshoe hare abundance and vegetation variables that were biologically meaningful. We computed $\mathrm{AIC}_{c}$, the second-order AIC for small sample size, and Akaike weights $\left(w_{i}\right)$ and made inferences from these models following 
TABLE 1: Description of and Pearson correlation coefficients among 4 variables considered for inclusion in linear regression models for explaining microsite use by snowshoe hares within 25 stands during winters 1996 and 1998, northcentral Maine.

\begin{tabular}{|c|c|c|c|c|c|}
\hline Variable & Description & $\mathrm{CC}$ & ULFD & SCU & BA \\
\hline Canopy closure (CC) & Percent overhead canopy closure & 1.000 & & & \\
\hline Understory lateral foliage density (ULFD) & Percent understory lateral foliage density & -0.305 & 1.000 & & \\
\hline Stem cover units (SCU) & $3 \times$ coniferous saplings + deciduous saplings $/$ ha & -0.324 & 0.448 & 1.000 & \\
\hline Basal area $(\mathrm{BA})$ & Basal area $\left(\mathrm{m}^{2} / \mathrm{ha}\right)$ of snags and deciduous and coniferous trees & 0.828 & -0.610 & -0.267 & 1.00 \\
\hline
\end{tabular}

TABLE 2: Akaike's Information Criterion adjusted for small sample size ( $\mathrm{AIC}_{\mathrm{c}}$ ) for the a priori set of candidate models considered to examine the influence of stem cover units (SCU $=3 \times$ coniferous saplings + deciduous saplings/ha), percent overhead canopy closure (CC), basal area $\left(\mathrm{m}^{2} / \mathrm{ha}\right)$ of snags and deciduous and coniferous trees (BA), and percent understory lateral foliage density (ULFD) on snowshoe hare pellet density (pellets/ha/month) within 25 microsite plots during winters 1996 and 1998, north-central Maine.

\begin{tabular}{|c|c|c|c|c|c|c|c|}
\hline Model $^{\mathrm{a}}$ & Rank & $K^{\mathrm{b}}$ & $\log (L)^{\mathrm{c}}$ & $\mathrm{AIC}_{\mathrm{c}}$ & $\Delta \mathrm{AIC}_{\mathrm{c}}$ & Model likelihood & $w_{i}^{\mathrm{d}}$ \\
\hline $\mathrm{SCU}+\mathrm{CC}$ & 1 & 4 & -224.69 & 459.37 & 0 & 1.00 & 0.81 \\
\hline SCU & 2 & 3 & -227.80 & 462.74 & 3.36 & 0.19 & 0.15 \\
\hline $\mathrm{SCU}+\mathrm{CC}+\mathrm{BA}+\mathrm{ULFD}$ & 3 & 6 & -224.47 & 465.60 & 6.23 & 0.04 & 0.04 \\
\hline CC + ULFD & 4 & 4 & -235.48 & 480.97 & 21.59 & 0 & 0 \\
\hline $\mathrm{CC}$ & 5 & 3 & -237.07 & 481.29 & 21.92 & 0 & 0 \\
\hline $\mathrm{BA}$ & 6 & 3 & -237.97 & 483.08 & 23.71 & 0 & 0 \\
\hline ULFD & 7 & 3 & -238.39 & 483.91 & 24.54 & 0 & 0 \\
\hline YEAR & 8 & 3 & -238.47 & 484.07 & 24.70 & 0 & 0 \\
\hline $\mathrm{ULFD}+\mathrm{BA}$ & 9 & 4 & -237.35 & 484.70 & 25.33 & 0 & 0 \\
\hline
\end{tabular}

${ }^{\mathrm{a}} \mathrm{SCU}$ : positive effect on snowshoe hare pellet density; CC: negative effect; BA: negative effect; ULFD: positive effect.

${ }^{\mathrm{b}} K$ : number of estimable parameters.

${ }^{\mathrm{c}} \log (L)$ : $\log$-likelihood $=-n / 2 * \log \left(\widehat{\sigma}^{2}\right)$ (Burnham and Anderson 2002 [47]).

${ }^{\mathrm{d}} w_{i}$ : Akaike weight.

the methods of Burnham and Anderson [47]. We calculated $\mathrm{AIC}_{\mathrm{c}}$ using the residual sum of squares from least-squares models [47]. We rescaled $\mathrm{AIC}_{\mathrm{c}}$ values relative to the best model, which received a $\triangle \mathrm{AIC}_{\mathrm{c}}$ value of zero. This model was considered the best model to approximate the data given the set of models considered. Values of $\Delta \mathrm{AIC}_{\mathrm{c}}$ from 0 to 2 were considered to have substantial support as being the $\mathrm{K}$ $\mathrm{L}$ best model of the candidate set [47]. We also calculated the likelihood of the model $\left(\exp \left((-1 / 2) \Delta_{i}\right)\right)$ to determine the relative strength of evidence for each model.

\section{Results}

3.1. Snowshoe Hare Model. Average canopy cover among the 25 microsite grids sampled was $65.56 \%(\mathrm{SE}=6.05)$, basal area averaged $20.71 \mathrm{~m}^{2} / \mathrm{ha}(\mathrm{SE}=2.98)$, stem cover units averaged $14,376 /$ ha $(\mathrm{SE}=2,406)$, and understory lateral foliage density averaged $55.95 \%(\mathrm{SE}=4.52)$.

Correlation among variables was $<|0.83|$ (Table 1). We used a squared transformation of canopy closure to meet parametric assumptions of normality [49]. The top ranked model $\left(\Delta \mathrm{AIC}_{\mathrm{c}}=0.00\right.$, likelihood $=1.00$, adjusted $r^{2}=0.71$, Table 2) was SCU (positive association, $B=0.93, \mathrm{SE}=0.15$ ) + overhead canopy closure (negative association, $B=-1.49$, $\mathrm{SE}=0.60$ ), and the predictive equation for that model was pellets $/$ ha/month $=204.12+0.93 \times$ SCU $-1.49 \times$ canopy $^{2}$. The Akaike weight for the top-ranked model (SCU + CC) was 0.81 . The second ranked model was the single variable model
$\operatorname{SCU}\left(\Delta \mathrm{AIC}_{\mathrm{c}}=3.36\right.$, likelihood $=0.19, r^{2}=0.65$, Table 2$)$. The combined Akaike weights for the top two models were 0.96 (Table 2), suggesting that SCU and canopy closure are the 2 most important variables among the suite of variables considered and best explain areas that had the greatest use by snowshoe hares within the 25 microsite grids that we sampled. We note that one pellet grid had pellet density and SCU greater than twice that of all other grids (Figure 3(b)), and this data point may have been influential. There was no effect of year on our estimates of pellet density.

Average pellet density within microsite grids with $<77 \%$ canopy closure was 16,431 pellets/ha/month $(\mathrm{SE}=6,332, n=$ 11). When canopy closure exceeded $77 \%$, pellet density was reduced to $<8,000$ pellets $/$ ha/month $(\bar{x}=977, \mathrm{SE}=563, n=$ 14). Microsites with stem cover units $\geq 22,000$ stems/ha had an average pellet density of 25,244 pellets/ha/month ( $\mathrm{SE}=8,300$, $n=7)$, but pellet density was reduced to 983 pellets $/$ ha/month $(\mathrm{SE}=510, n=18)$ when stem cover units were $<22,000$ stems/ha (Figure 3 ). The five microsite grids with the highest pellet density ( $>23,000$ pellets/ha/month) had canopy closure $<72 \%$ and stem cover units $>22,000$ stems $/$ ha.

\section{Discussion}

Microsite-scale habitat use by snowshoe hares was positively associated with understory cover and negatively associated with canopy closure, suggesting that areas within stands that have dense understories of coniferous and deciduous saplings 


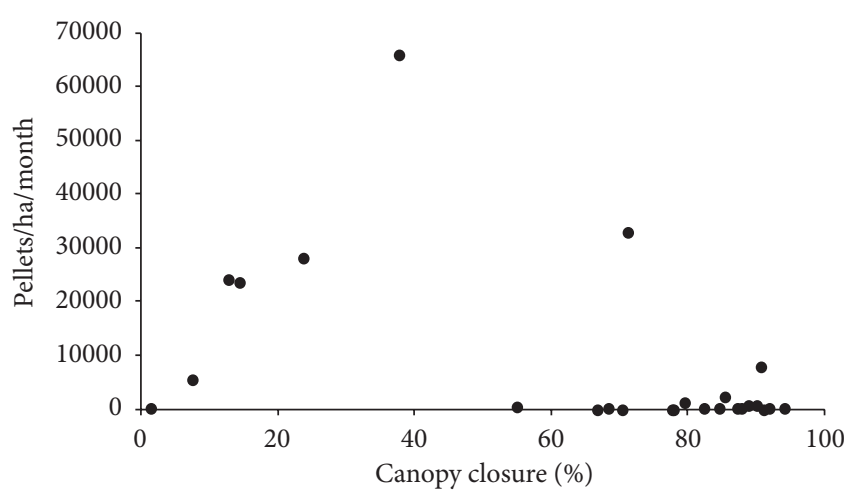

(a)

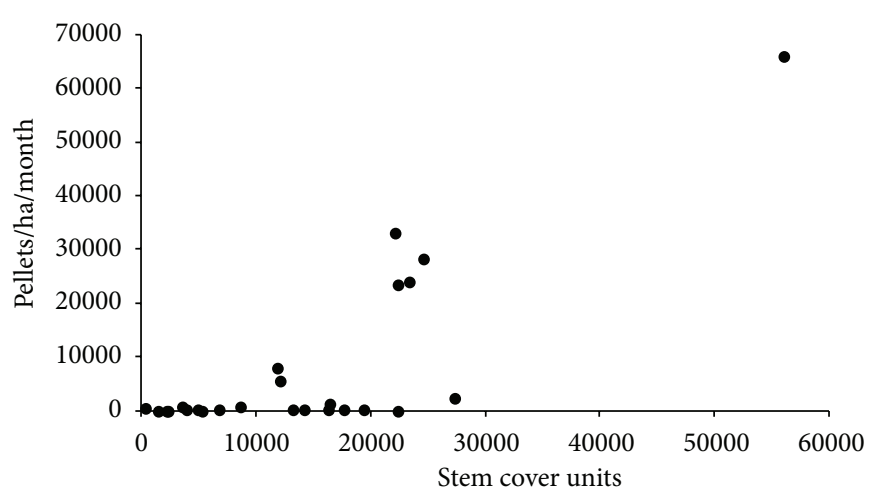

(b)

FIGURE 3: Relationship between snowshoe hare pellet density (pellets/ha/month) and covariates canopy closure (\%) (a) and stem cover units $(3 \times$ conifer saplings + deciduous saplings $)$ per ha (b) across 25 pellet grids, from the best approximating model.

are important in maintaining high habitat use by hares. Our results at the microsite scale are consistent with results that have been documented at larger spatial scales but suggest that within-patch variability may promote localized use of areas of high stem cover. These dense areas within stands may also promote the ability of hares to browse in close proximity to cover [23]. Dense understories are important to hares because they provide foraging opportunities $[24,26]$ and are a refuge from predation by species such as lynx that typically do not kill snowshoe hares in stands with the densest understories $[16,17,50]$. Dense stands have been documented to have higher survival rates of hares than open stands, likely a result of increased hiding cover [20]. Woody stems and conifer needles impair visibility and mobility of predators of hares, which were responsible for the majority of hare mortalities in Wisconsin [51] and areas outside of predator exclosures in the Yukon Territory, Canada [50].

Additional evidence to suggest that understory cover is also a primary determinant of stand-scale habitat quality for snowshoe hares was documented in precommercially thinned stands in Maine. Precommercially thinned regenerating clearcut stands were associated with reduced horizontal cover and structural diversity compared to unthinned stands [52] and resulted in snowshoe hare densities $<50 \%$ of those observed in unthinned stands [53], despite maintaining similar species composition and forage value. Hares forage on a wide variety of plant and tree species, and evidence suggests that they may select dense understory cover regardless of the plant species composition and food value $[22,24,26]$. As demonstrated in our study, across 25 microsite grids of varying species composition and structure, there was a positive relationship between areas of high relative pellet density and the density of understory saplings.

Within-stand scale habitat use by hares is typically dominated by understory structure and not by canopy closure $[21,28]$. Overstory cover is sometimes correlated with habitat use by hares, but most often when it is correlated with understory cover $[14,27]$. However, we observed a low $(r=$ 0.32 ) negative correlation between overhead canopy closure and stem cover units within the microsites that we sampled, suggesting that there may be more complex interactions between understory structure, overhead canopy closure, and within-stand patchiness that may warrant further study.

We acknowledge that pellet density may not provide the most precise indirect measure of relative abundance of snowshoe hares because of temporal changes in hare abundance, pellet loss, and pellet decomposition rates resulting from diet or climate $[42,54]$. Despite these limitations, pellet counts from both cleared and uncleared plots have been found to be highly correlated with density of snowshoe hares $[42,46,54]$. We cleared our pellet plots, which have been found to have greater precision on estimates of relative abundance of hares than uncleared plots [45]. Further, we were not using pellet density as an estimate of hare density across stand types but instead used it only to evaluate the relative extent of use of microsite characteristics within stands. Further, we recognize that annual changes in regional and stand-scale hare densities can be caused by extrinsic population processes such as dispersal, climate, and predator-prey dynamics $[1,55]$. There is likely to be a great deal of temporal and spatial variation in hare abundance or pellet density that is attributed to factors other than vegetation structure, and we acknowledge that there may be additional factors that we did not measure which could influence pellet density (albeit most would operate at the scales of individual home ranges or broader). As such, we encourage additional studies of hare habitat use during periods of relatively lower hare abundance.

Although our data does not allow us to provide threshold levels of canopy closure or stem cover units, we observed that pellet densities were greater than 23,000 pellets/ha/month at 5 of 5 plots with canopy closure $<72 \%$ and SCU $>22,000$ stems/ha and were $<8,000$ pellets/ha/month at 12 of 14 plots with canopy closure $>76 \%$ and SCU $<22,000$ stems $/$ ha. We caution that these values are based on data from one study site and could vary based on the addition of additional sites or additional study areas. There could be a threshold response to stem density where, at extremely high densities, hare use could decline. However, we are unable to provide insights into stem densities higher than the values we observed in our study. Stem cover units of 22,000 stems/ha equated to 
an average density of $6,719(\mathrm{SE}=1,936)$ conifer stems/ha, which is very close to the previously recommended minimum of 7,000 conifer stems/ha to maintain high quality habitat for Canada lynx [17]. We note that the recommendation for lynx habitat is based on stand-scale characteristics and that our recommendations for hares in this study are at the microsite level. As such, hares appear to be exhibiting similar patterns of use across scales; however, our findings do not consider landscape-scale effects of matrix quality, which could influence stand structure use by hares at a microsite scale. The recommendations at both the microsite and stand scales are consistent, suggesting that habitat use by hares is strongly associated with conifer and deciduous saplings that are in the stage of stem exclusion and self-thinning with reduced overstory canopies. In the Acadian forest of eastern North America, these stand conditions typically occur 1035 years following partial or complete overstory removal $[17,34]$. We recommend additional work to more specifically elucidate the precise threshold of canopy closure and SCUs for which managers should strive to maximize hare use after forest harvesting.

\section{Acknowledgments}

The authors thank H. J. Lachowski for providing hare pellet counts that were collected as part of his Master's thesis. They thank field technicians A. Ash, S. Becker, J. Berube, T. Gorman, B. Kidder, M. Loud, A. McCue, R. Parker, S. Pastva, G. Pelton, P. Reaman, B. Richardson, A. Vashon, N. Wildman, and D. Wrobleski. This project was funded by the Maine Cooperative Forestry Research Unit, the Maine Agricultural and Forest Experiment Station at the University of Maine, US National Park Service, by Federal Aid in Wildlife Restoration Project no. W-82-R-11-368, and the Department of Wildlife Ecology at the University of Maine. This is Scientific Contribution no. 3337 of the Maine Agricultural and Forest Experiment Station. This work is based upon research supported, in part, by McIntire-Stennis Grant MEO9660-05 from the USDA National Institute of Food and Agriculture.

\section{References}

[1] C. J. Krebs, S. Boutin, and R. Boonstra, Ecosystem Dynamics of the Boreal Forest: The Kluane Project, Oxford University Press, New York, NY, USA, 2001.

[2] P. R. Sievert and L. B. Keith, "Survival of snowshoe hares at a geographic range boundary," The Journal of Wildlife Management, vol. 49, no. 4, pp. 854-866, 1985.

[3] F. J. Dibello, S. M. Arthur, and W. B. Krohn, "Food habits of sympatric coyotes, red foxes, Vulpes vulpes, and bobcats, Lynx rufus, in Maine," Canadian Field Naturalist, vol. 104, no. 3, pp. 403-408, 1990.

[4] M. O’Donoghue, S. Boutin, and C. Krebs, "Behavioural responses of coyotes and lynx to the snowshoe hare cycle," Oikos, vol. 82, no. 1, pp. 169-183, 1998.

[5] S. M. Arthur, W. B. Krohn, and J. R. Gilbert, "Habitat use and diet of fishers," The Journal of Wildife Management, vol. 53, no. 3, pp. 680-688, 1989.
[6] S. Martin, "Feeding ecology of American martens and fishers," in Martens, Sables, and Fishers: Biology and Conservation, S. Buskirk, A. Harestad, M. Raphael, and R. A. Powell, Eds., pp. 297-315, Cornell University Press, Ithaca, NY, USA, 1994.

[7] W. J. Zielinski, W. D. Spencer, and R. H. Barrett, "Relationship between food habits and activity patterns of pine martens," Journal of Mammalogy, vol. 64, no. 3, pp. 387-396, 1983.

[8] I. D. Thompson and P. W. Colgan, "Numerical responses of martens to a food shortage in northcentral Ontario," The Journal of Wildlife Management, vol. 51, no. 4, pp. 824-835, 1987.

[9] A. K. Fuller and D. J. Harrison, "Influence of partial timber harvesting on American martens in North-Central Maine," The Journal of Wildlife Management, vol. 69, no. 2, pp. 710-722, 2005.

[10] J. T. Major and J. A. Sherburne, "Interspecific relationships of coyotes, bobcats, and red foxes in western Maine," The Journal of Wildlife Management, vol. 51, no. 3, pp. 606-616, 1987.

[11] J. K. Saunders Jr., "Food habits of the lynx in Newfoundland," The Journal of Wildlife Management, vol. 27, no. 3, pp. 384-390, 1963.

[12] C. Brand and L. Keith, "Lynx demography during a snowshoe hare decline in Alberta," The Journal of Wildlife Management, vol. 43, no. 4, pp. 827-849, 1979.

[13] U S Fish and Wildlife Service, "Endangered and threatened wildlife and plants: determination of threatened status for the contiguous United States distinct population segment of the Canada lynx and related rule, final rule," Federal Register, vol. 65, no. 58, pp. 16052-16086, 2000.

[14] G. R. Parker, J. W. Maxwell, L. D. Morton, and G. E. J. Smith, "The ecology of the lynx (Lynx canadensis) on Cape Breton Island (snowshoe hare Lepus americanus)," Canadian Journal of Zoology, vol. 61, no. 4, pp. 770-786, 1983.

[15] G. M. Koehler, "Population and habitat characteristics of lynx and snowshow hares in north central Washington," Canadian Journal of Zoology, vol. 68, no. 5, pp. 845-851, 1990.

[16] G. Mowat, K. Poole, and M. O’Donoghue, "Ecology of lynx in northern Canada and Alaska," in Ecology and Conservation of Lynx in the United States, L. Ruggiero, K. B. Aubry, S. Buskirk et al., Eds., pp. 265-306, University Press of Colorado, Boulder, Colo, USA, 2000.

[17] A. K. Fuller, D. J. Harrison, and J. H. Vashon, "Winter habitat selection by Canada lynx in Maine: prey abundance or accessibility?" The Journal of Wildlife Management, vol. 71, no. 6, pp. 1980-1986, 2007.

[18] J. R. Squires and L. F. Ruggiero, "Winter prey selection of Canada lynx in Northwestern Montana," The Journal of Wildlife Management, vol. 71, no. 2, pp. 310-315, 2007.

[19] T. P. Sullivan and R. A. Moses, "Demographic and feeding responses of a snowshoe hare population to habitat alteration," Journal of Applied Ecology, vol. 23, no. 1, pp. 53-63, 1986.

[20] P. C. Griffin and L. S. Mills, "Sinks without borders: snowshoe hare dynamics in a complex landscape," Oikos, vol. 118, no. 10, pp. 1487-1498, 2009.

[21] K. E. Hodges, "The ecology of snowshoe hares in northern boreal forests," in Ecology and Conservation of Lynx in the United States, L. F. Ruggiero, K. B. Aubry, S. W. Buskirk, G. M. Koehler, K. S. Mckelvey, and J. R. Squires, Eds., pp. 117-161, University Press of Colorado, Boulder, Colo, USA, 2000.

[22] J. Wolff, "The role of habitat patchiness in the population dynamics of snowshoe hares," Ecological Monographs, vol. 50, no. 1, pp. 111-130, 1980. 
[23] K. E. Hodges and A. R. E. Sinclair, "Browse site selection by snowshoe hares: effects of food supply and predation risk," Canadian Journal of Zoology, vol. 83, no. 2, pp. 280-292, 2005.

[24] J. Ferron and J.-P. Ouellet, "Daily partitioning of summer habitat and use of space by the snowshoe hare in southern boreal forest," Canadian Journal of Zoology, vol. 70, no. 11, pp. 2178-2183, 1992.

[25] M. Wolfe, N. DeByle, C. Winchell, and T. McCabe, "Snowshoe hare cover relationships in northern Utah," The Journal of Wildlife Management, vol. 46, no. 3, pp. 662-670, 1982.

[26] J. A. Litvaitis, J. A. Sherburne, and J. A. Bissonette, "Influence of understory characteristics on snowshoe hare habitat use and density," The Journal of Wildlife Management, vol. 49, no. 4, pp. 866-873, 1985.

[27] C. Orr and D. G. Dodds, "Snowshoe hare habitat preferences in Nova Scotia spruce-fir forests," Wildlife Society Bulletin, vol. 10, pp. 147-150, 1982.

[28] A. J. Wirsing, T. D. Steury, and D. L. Murray, "A demographic analysis of a southern snowshoe hare population in a fragmented habitat: evaluating the refugium model," Canadian Journal of Zoology, vol. 80, no. 1, pp. 169-177, 2002.

[29] L. B. Keith, J. R. Cary, O. J. Rongstad, and M. C. Brittingham, "Demography and ecology of a declining snowshoe hare population," Wildlife Monographs, no. 90, pp. 3-43, 1984.

[30] C. W. Lewis, K. E. Hodges, G. M. Koehler, and L. S. Mills, "Influence of stand and landscape features on snowshoe hare abundance in fragmented forests," Journal of Mammalogy, vol. 92, no. 3, pp. 561-567, 2011.

[31] N. D. Berg, E. M. Gese, J. R. Squires, and L. M. Aubry, "Influence of forest structure on the abundance of snowshoe hares in western Wyoming," The Journal of Wildlife Management, vol. 76, no. 7, pp. 1480-1488, 2012.

[32] D. A. Buehler and L. B. Keith, "Snowshoe hare distribution and habitat use in Wisconsin," Canadian Field-Naturalist, vol. 96, no. 1, pp. 19-29, 1982.

[33] K. E. Hodges, "Ecology of snowshoe hares in southern boreal and montane forests," in Ecology and Conservation of Lynx in the United States, L. Ruggiero, K. B. Aubry, S. W. Buskirk et al., Eds., pp. 163-207, University Press of Colorado, Boulder, Colo, USA, 2000

[34] J. A. Homyack, D. J. Harrison, J. A. Litvaitis, and W. B. Krohn, "Quantifying densities of snowshoe hares in Maine using pellet plots," Wildlife Society Bulletin, vol. 34, no. 1, pp. 74-80, 2006.

[35] D. E. Ausband and G. R. Baty, "Effects of precommercial thinning on snowshoe hare habitat use during winter in lowelevation montane forests," Canadian Journal of Forest Research, vol. 35, no. 1, pp. 206-210, 2005.

[36] J. A. Litvaitis, Bobcat Movements in Relation to Prey Density, University of Maine, Orono, Me, USA, 1984.

[37] J. A. Litvaitis, J. A. Sherburne, and J. A. Bissonette, "A comparison of methods used to examine snowshow hare habitat use," The Journal of Wildlife Management, vol. 49, no. 3, pp. 693-695, 1985.

[38] M. Darveau, J. Huot, and L. Bélanger, "Riparian forest strips as habitat for snowshoe hare in a boreal balsam fir forest," Canadian Journal of Forest Research, vol. 28, no. 10, pp. 14941500, 1998.

[39] F. Potvin, L. Breton, and R. Courtois, "Response of beaver, moose, and snowshoe hare to clear-cutting in a Quebec boreal forest: a reassessment 10 years after cut," Canadian Journal of Forest Research, vol. 35, no. 1, pp. 151-160, 2005.
[40] C. J. Krebs, B. S. Gilbert, S. Boutin, and R. Boonstra, "Estimation of snowshoe hare population density from turd transects," Canadian Journal of Zoology, vol. 65, no. 3, pp. 565-567, 1987.

[41] D. L. Murray, J. D. Roth, E. Ellsworth, A. J. Wirsing, and T. D. Steury, "Estimating low-density snowshoe hare populations using fecal pellet counts," Canadian Journal of Zoology, vol. 80, no. 4, pp. 771-781, 2002.

[42] L. S. Mills, P. C. Griffin, K. E. Hodges, K. McKelvey, L. Ruggiero, and T. Ulizio, "Pellet count indices compared to mark-recapture for evaluating snowshoe hare density," The Journal of Wildlife Management, vol. 69, no. 3, pp. 1053-1062, 2005.

[43] D. Murray, E. Ellsworth, and A. Zack, "Assessment of potential bias with snowshoe hare fecal pellet-plot counts," The Journal of Wildlife Management, vol. 69, no. 1, pp. 385-395, 2005.

[44] P. Lemon, "A spherical densiometer for measuring forest overstory density," Forest Science, vol. 2, pp. 314-320, 1956.

[45] N. D. Berg and E. M. Gese, "Relationship between fecal pellet counts and snowshoe hare density in western Wyoming," The Journal of Wildlife Management, vol. 74, no. 8, pp. 1745-1751, 2010.

[46] B. Griffith and B. A. Youtie, "Two devices for estimating foliage density and deer hiding cover," Wildlife Society Bulletin, vol. 16, no. 2, pp. 206-210, 1988.

[47] K. P. Burnham and D. R. Anderson, Model Selection and Multimodel Inference: A Practical Information-Theoretic Approach, Springer, New York, NY, USA, 2nd edition, 2002.

[48] J. Neter, M. Kutner, C. Nachtsheim, and W. Wasserman, Applied Linear Statistical Models, Irwin, Boston, Mass, USA, 4th edition, 1996.

[49] J. Zar, Biostatistical Analysis, Prentice-Hall, Englewood Cliffs, NJ, USA, 4th edition, 1999.

[50] K. E. Hodges, C. J. Krebs, D. Hik, C. Stefan, E. A. Gillis, and C. E. Doyle, "Snowshoe hare demography," in Ecosystem Dynamics of the Boreal Forest: The Kluane Project, C. J. Krebs, S. Boutin, and R. Boonstra, Eds., pp. 141-178, Oxford University Press, New York, NY, USA, 2001.

[51] L. B. Keith, S. E. M. Bloomer, and T. Willebrand, "Dynamics of a snowshoe hare population in fragmented habitat," Canadian Journal of Zoology, vol. 71, no. 7, pp. 1385-1392, 1993.

[52] J. A. Homyack, D. J. Harrison, and W. B. Krohn, "Structural differences between precommercially thinned and unthinned conifer stands," Forest Ecology and Management, vol. 194, no. 13, pp. 131-143, 2004.

[53] J. A. Homyack, D. J. Harrison, and W. B. Krohn, "Effects of precommercial thinning on snowshoe hares in Maine," The Journal of Wildlife Management, vol. 71, no. 1, pp. 4-13, 2007.

[54] B. E. Kendall, O. N. Bjørnstad, J. Bascompte, T. H. Keitt, and W. F. Fagan, "Dispersal, environmental correlation, and spatial synchrony in population dynamics," American Naturalist, vol. 155, no. 5, pp. 628-636, 2000.

[55] N. C. Stenseth, D. Ehrich, E. K. Rueness et al., "The effect of climatic forcing on population synchrony and genetic structuring of the Canadian lynx," Proceedings of the National Academy of Sciences of the United States of America, vol. 101, no. 16, pp. 6056-6061, 2004. 

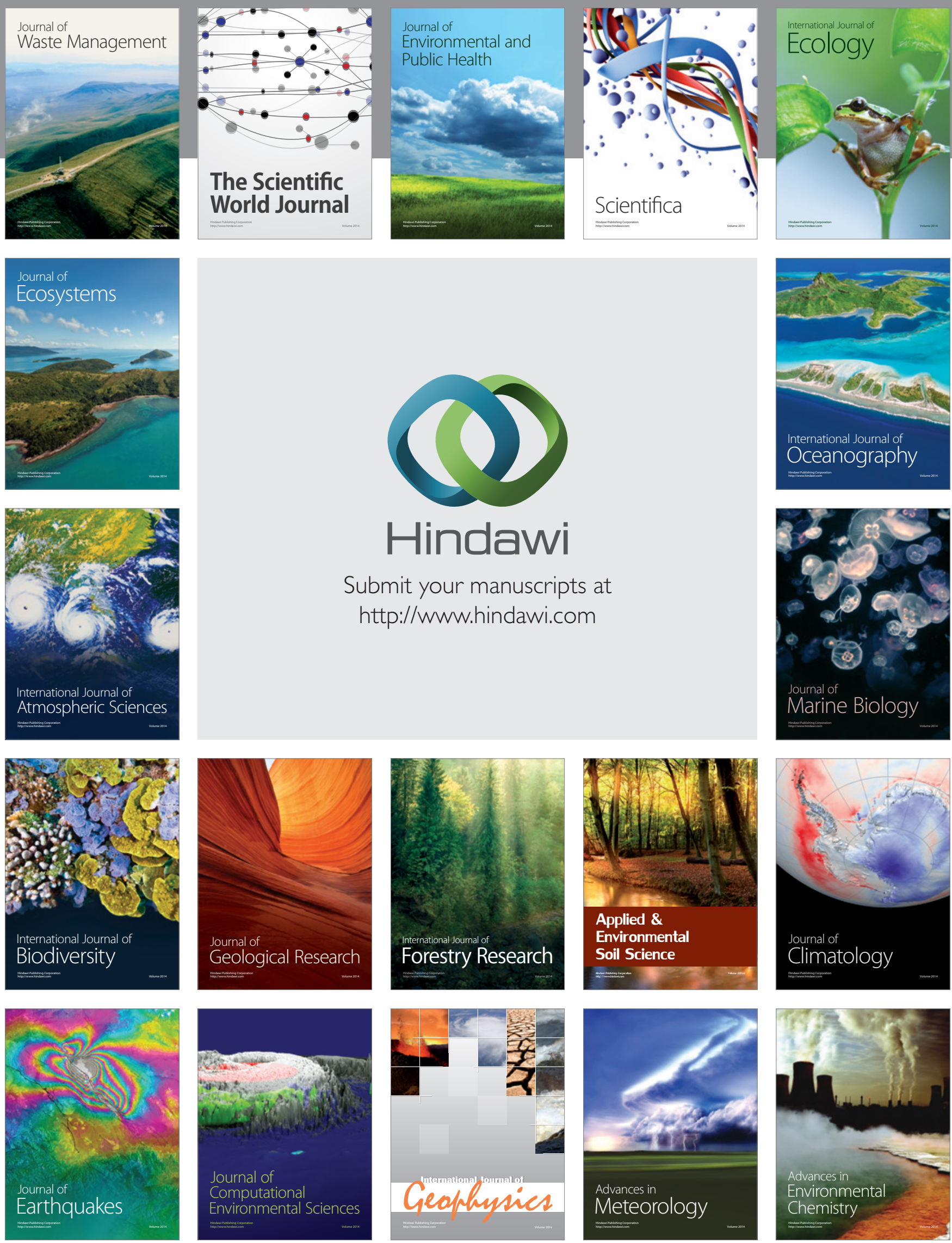